\title{
Loss of Acetylcholine Receptor Clusters Induced by Treatment of Cultured Rat Myotubes with Carbachol
}

\author{
Robert J. Bloch \\ Department of Physiology, University of Maryland School of Medicine, Baltimore, Maryland 21201
}

Prolonged exposure to carbachol disrupts the acetylcholine receptor (AChR) clusters of cultured rat myotubes without causing myotube loss. The effect is reversible, and is dependent on temperature. Half-maximal cluster loss is achieved at $3 \mu \mathrm{M}$ carbachol. Cluster loss is also caused by other agonists of the AChR and is blocked by receptor antagonists. QX314 (a lidocaine derivative), meproadifen, and fluphenazine also completely block cluster loss caused by carbachol. These results are consistent with the idea that cluster loss caused by carbachol and other receptor agonists results from their interaction with the $A C h R$, and the consequent influx of cations into the myotubes. Several experiments suggest that extracellular $\mathrm{Na}^{+}$and $\mathrm{Ca}^{2+}$ are required, and that at least $\mathrm{Na}^{+}$must permeate the $\mathrm{AChR}$ ion channel for full cluster loss to occur in the presence of carbachol. Depolarization alone is not sufficient to cause cluster loss, however. $\mathrm{Ca}^{2+}$-activated proteases do not play a significant role in carbachol-induced cluster loss.

The clustering of acetylcholine receptors (AChR) at sites of nervemuscle contact is one of the earliest events in the differentiation of the postsynaptic region of the neuromuscular junction (Fambrough, 1979). To understand the synaptogenic interactions between nerve and muscle, I have been studying AChR clustering, in vivo and in vitro, in aneural cultures of rat myotubes. The organization and properties of the AChR clusters in newly innervated muscle and in cultured myotubes seem to be similar in the rat (Steinbach and Bloch, in press). One similarity is that AChR clusters in cultured rat myotubes and at the embryonic postsynaptic membrane are susceptible to disruption by prolonged treatment with carbachol, an AChR agonist (Bloch, 1979; Bloch and Steinbach, 1981). To learn more about this phenomenon, I have studied the factors involved in carbachol-induced AChR cluster loss in cultured cells.

In the experiments reported here, I show, first, that carbachol does not exert its effect by causing loss or irreversible damage to myotubes, and, second, that it destabilizes AChR clusters by interacting with the nicotinic receptor. I then consider three actions of carbachol that could destabilize AChR clusters: (1) the conformational change induced in the receptor by binding

Received Feb. 27, 1985; revised May 20, 1985; accepted June 11, 1985.

I thank Dr. Stephen Heinemann, in whose laboratory at the Salk Institute (La Jolla, CA) much of this work was performed, for his encouragement and financial support. I also thank Dr. P. Brehm for his measurements of membrane potential, and Drs. J. Patrick, J. H. Steinbach, and R. Gruener for their useful suggestions. Drs. D. Burt, L. Waxman, B. Krueger, and E. X. Albuquerque generously offered their reagents and advice, and Ms. W. Resneck assisted in some of the experiments. I began this work as a Fellow of the San Diego Chapter of the American Heart Association, with support from the Samuel Roberts Noble Foundation of Ardmore, OK, and from grants to Dr. Heinemann from the National Institutes of Health (NS 11549) and the Muscular Dystrophy Association. More recently, I have been supported by grants from the National Institutes of Health (NS 17282) and the Muscular Dystrophy Association, as well as by a McKnight Scholar's Award and a Research Career Development Award (NS 00679).

Copyright (C) 1986 Society for Neuroscience $0270-6474 / 86 / 030691-10 \$ 02.00 / 0$ of carbachol; (2) the cation flux into myotubes following the conformational change; (3) the depolarization following cation flux. I show that the second possibility, cation flux through the receptor channel, accounts for the destabilizing effect of carbachol on AChR clusters. These results arc consistent with the idea that the stability of the AChR clusters of cultured rat myotubes is dependent on the intracellular ionic milieu.

\section{Materials and Methods}

Mcthods for preparing myotubc cultures, for staining them with tetramethylrhodamine- $\alpha$-bungarotoxin (R-BT; Ravdin and Axelrod, 1977), and for analyzing $A C h R$ clusters have been presented in detail elsewhere (Bloch, 1979, 1983). In brief, rat myotube cultures, grown on glass coverslips, are washed with Dulbecco-Vogt modified Eagle's medium (DMEM) buffered with HEPES, then covered with DMEM containing $5 \%$ fetal calf (Gibco, Grand Island, NY) or cadet calf serum (Biocell Laboratories, Carson, $\mathrm{CA}$ ), and incubated with or without the addition of drugs for $6 \mathrm{hr}$ at $37^{\circ} \mathrm{C}$ in an atmosphere of $94 \%$ air, $6 \% \mathrm{CO}_{2}$. Cultures are washed extensively with HEPES-buffered DMEM, stained with R-BT, fixed, and observed under fluorescence optics to determine the percentage of the total myotubes displaying large, flat AChR clusters on their ventral surfaces.

A cluster is defined as a discrete region of the myotube surface, $\sim 40$ $\mu \mathrm{m}^{2}$ in area, that stains brightly with R-BT, is neither linear nor an artifact of the overlapping of two or more cells, and is not located on a cellular process isolated from the muscle cell or detached from the tissue culture substrate (Bloch, 1979). Usually 50 myotubes per culture were analyzed, and each experimental value is the average of duplicate or triplicate determinations. Values generally vary by $\pm 10 \%$ myotubes with clusters (e.g., Tables 3 and 5 , below).

Influx experiments with ${ }^{22} \mathrm{Na}^{+}$were performed as described by Bloch (1979) and Stallcup and Cohn (1976), except that the temperature was $35-37^{\circ} \mathrm{C}$, and incubations were performed for $15 \mathrm{~min}$. Longer exposure to carbachol before assay also resulted in increased ${ }^{22} \mathrm{Na}^{+}$influx, but was not as quantitatively reproducible and so was not pursued further.

The sources of most materials have been reported earlier (Bloch, 1979). Nicotinic and muscarinic cholinergic drugs and other neurotransmitter receptor ligands were purchased from Sigma Chemical Company (St. Louis, MO) or were gifts from Dr. J. Patrick (Neurobiology Laboratory, The Salk Institute, La Jolla, CA). Leupeptin, aprotinin, pepstatin, and L-seryl-L-leucine were purchased from Sigma. The protease inhibitor, Ep475, was kindly provided by Dr. L. Waxman (Department of Physiology, Harvard Medical School). Fluphenazine and meproadifen were the gifts of Drs. B. Krueger and E. Albuquerque (Departments of Physiology, and Pharmacology, respectively, University of Maryland School of Medicine).

\section{Results}

\section{Cluster loss caused by carbachol}

In cultures of rat myotubes, $70-90 \%$ of the myotubes normally display large clusters of AChR, which can be visualized after staining with R-BT. Upon exposure to $10^{-4} \mathrm{M}$ carbachol, the fraction of myotubes displaying clusters decreases to $<30 \%$ (Bloch, 1979). This loss of clusters occurs as a linear function of time up to $6 \mathrm{hr}$ (Fig. 1). As the effects of carbachol on AChR 


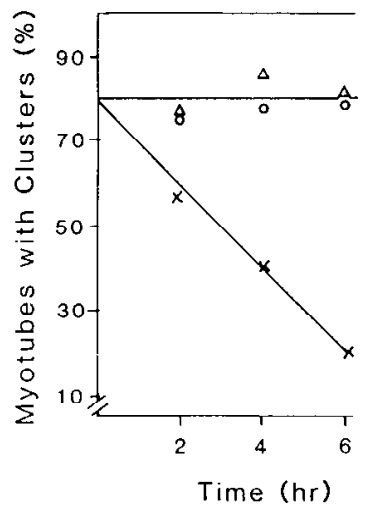

Figure 1. The time course of AChR cluster loss in the presence of carbachol. Myotube cultures were incubated in medium (open circles) or in medium containing either $10^{-4} \mathrm{M}$ carbachol (crosses) or $10^{-4} \mathrm{M}$ $d$-tubocurarine (triangles). At the times indicated, the cultures were removed from the incubator, washed extensively with buffered medium, stained with R-BT, and observed under fluorescence. Myotubes with AChR clusters were quantitated as described in Methods. The results show that cluster loss is induced by carbachol, but not by $d$-tubocurarine, and that it proceeds as a linear function of time of treatment.

clusters are apparent at $6 \mathrm{hr}$, this time was routinely used in the experiments presented here. Data in Figure 1 further suggest that the failure to detect $\mathrm{AChR}$ clusters was not due to incomplete removal of carbachol before staining with R-BT. For example, similar amounts of carbachol should remain after washing cells treated for 2 and $6 \mathrm{hr}$, but the percentage of myotubes with clusters at $6 \mathrm{hr}$ is one-third that seen after $2 \mathrm{hr}$ of treatment. Also, $d$-tubocurarine at $10^{-4} \mathrm{M}$ causes no loss of clusters, despite the fact that it has a higher affinity for AChR than does carbachol. Thus, residual carbachol does not compete with R-BT and prevent the visualization of $\mathrm{AChR}$ clusters. In the experiments presented below, I show that cluster loss is not the result of irreversible loss or damage sustained by myotubes, but is, instead, caused by carbachol interacting with the nicotinic $\mathrm{AChR}$ and inducing the influx of cations, primarily $\mathrm{Na}^{+}$, into the myotubes.

I first addressed the possibility that carbachol caused the loss of entire myotubes displaying clusters. A total of 194 cells in four myotube cultures were identified and photographed. Two cultures were incubated under control conditions, and two were incubated similarly but in the presence of $10^{-4} \mathrm{M}$ carbachol. The cultures were then stained with R-BT, and the identified cells were observed and rephotographed. The results (Table 1) show that most of the control cells were present after $6 \mathrm{hr}$ of incubation and that most of these displayed AChR clusters. Most of the carbachol-treated cells were also recovered after $6 \mathrm{hr}$, but only $4 \%$ of these had clusters. Examples are presented in Figure 2. The results indicate that carbachol causes AChR clusters to be lost without causing significant loss of muscle cells.

Carbachol-treated cells underwent some change in shape, however (Fig. 2, $A$ and $B$, white arrows). After treatment with $10^{-4} \mathrm{M}$ carbachol, the cusps of the myotubes appeared broader and the myotube sections connecting the cusps appeared narrower. Although these shape changes accompany the loss of clusters, more extensive changes in myotube shape are induced by colchicine, without extensive cluster loss (Bloch, 1979, 1983), suggesting that alteration of myotube shape is itself not sufficient to cause loss of AChR clusters. Vacuolization, observed in some carbachol-treated cells (Fig. $2 B$, black arrowhead) did not always accompany loss of AChR clusters, as less than $15 \%$ of the muscle cells became vacuolated during exposure to carbachol.

I next determined if the effect of carbachol on AChR clusters was reversible. After exposure to $10^{-4} \mathrm{M}$ carbachol for $6 \mathrm{hr}$, cultures were washed extensively in fresh medium and incu-
Table 1. Effect of carbachol on AChR clusters and number of myotubes

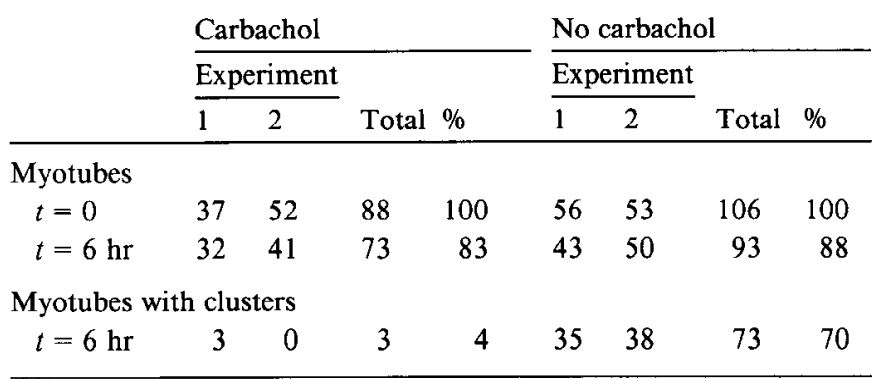

Myotube cultures on glass coverslips were mounted into a special incubation chamber (Anderson et al., 1977). Selected fields were photographed at low magnification, and their grid positions were noted. These photographs subsequently gave the number of myotubes present in the selected fields at the beginning of the experiment $(t=0)$. The cultures were then placed into a solution consisting of DMEM plus $5 \%$ cadet calf serum. Half of the chambers also contained $10^{-4} \mathrm{M}$ carbachol. Cultures were incubated for $6 \mathrm{hr}$ at $37^{\circ} \mathrm{C}$, washed free of the incubation medium and stained with R-BT. After staining, the cultures were fixed in $2 \%$ paraformaldehyde. The same grid positions were relocated and photographed. These photographs subsequently gave the number of myotuhes present in the same fields at the termination of the experiment $(t=6 \mathrm{hr})$. The myotubes in these selected fields were then observed with fluorescence optics under high magnification to determine whether AChR clusters were present, as outlined in Methods. These data are contained in the row labeled "Myotubes with clusters," $t=6 \mathrm{hr}$.

bated for an additional $18 \mathrm{hr}$. Upon staining with R-BT, most of the myotubes present at the end of the experiment contained AChR clusters (see Table 2). Similar results were obtained when myotube cultures were stained with R-BT after the $6 \mathrm{hr}$ exposure to carbachol but before the $18 \mathrm{hr}$ recovery period (see Table 2). Thus, all the clusters seen after the $18 \mathrm{hr}$ recovery contained AChRs that were present before recovery began. This suggests that the reappearance of $\mathrm{AChR}$ clusters was not due to the formation of new myotubes during the recovery period. The possibility that massive loss of muscle cells occurred during the recovery period was ruled out by measuring the number of ${ }^{125} \mathbf{I}-$ BT binding sites in the cultures immediately after carbachol treatment and again after recovery. In two experiments, ${ }^{125} \mathrm{I}-\mathrm{BT}$ binding was 34 and $41 \%$ greater after recovery than immediately after the $6 \mathrm{hr}$ treatment with carbachol. Together with the data in Table 2, this finding rules out the possibility that the cells left after recovery were only those cells that resisted the effects of carbachol. I conclude that the carbachol-induced loss of AChR clusters is reversible.

I observed the disruptive effects of carbachol on AChR clusters in all the experiments (total of 59) I performed. In $12(20 \%)$ of these experiments, however, the effect of carbachol treatment was quantitatively diminished, resulting in $40-55 \%$ of myotubes with clusters after $6 \mathrm{hr}$, rather than the usual $20-30 \%$. This variability may depend on the statc of devclopment of the cultures, but I have not found a consistent effect either of culture age or of initial plating density. Unless otherwise stated, the results reported here represent only those experiments in which carbachol treatment resulted in $<40 \%$ of myotubes with clusters. The experiments that have been omitted always gave qualitatively similar results. Quantitatively, however, drugs that block AChR cluster loss in the presence of carbachol are generally more potent when carbachol-induced cluster loss is diminished.

Recently, considerable attention has been given to the AChR clusters that form on the dorsal or upper myotube surface, distant from the tissue culture substrate. Dorsal clusters, too, are destabilized by carbachol: In two experiments, the percent of myotubes with dorsal clusters decreased by 40 and $69 \%$, as compared to controls. The effects of carbachol on the ventral clusters were quantitatively similar. In my cultures, dorsal clusters are generally infrequent and more variable than are ventral clusters (from 23 to $51 \%$ myotubes with dorsal clusters, in six 

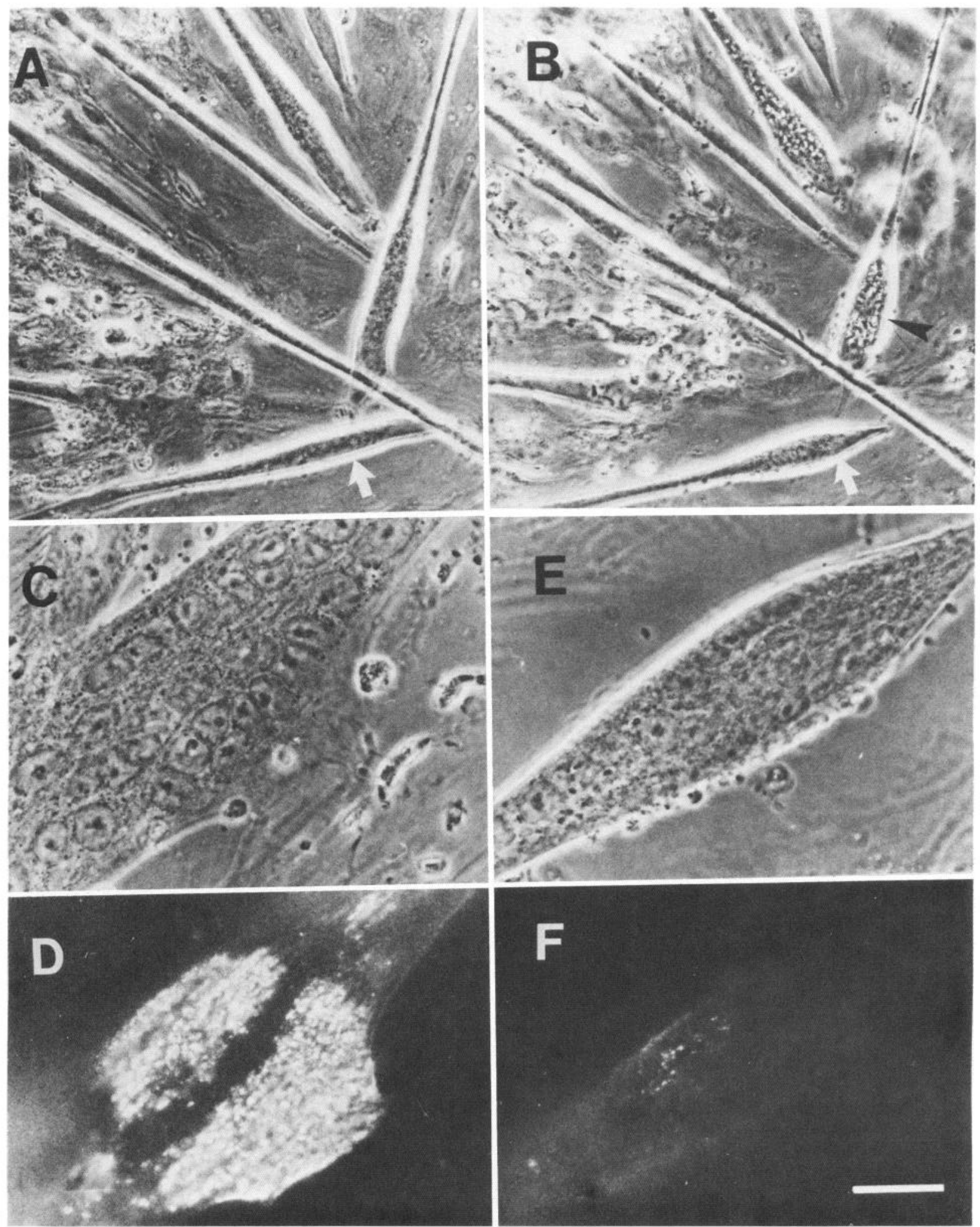

Figure 2. The effect of carbachol on cell number and AChR clusters in identified cells. Cultures were processed as described in the legend to Table 1. At the beginning of the experiment, phase micrographs were taken of control cultures (not shown) and of cultures to which carbachol had just been added $(A)$. Cultures were then replaced at $37^{\circ} \mathrm{C}$ for $6 \mathrm{hr}$. After this incubation, cultures were labeled with R-BT and fixed with paraformaldehyde. The same fields were relocated and photographed again $(B$, for carbachol-treated sample). The magnification was then increased, and individual control $(C, D)$ and carbachol-treated $(E, F)$ cells were examined and photographed under phase $(C, E)$ and fluorescence $(D, F)$ illumination to determine if AChR clusters were present. Panels $E$ and $F$ show the cell marked with the white arrow in $B$. This figure shows that most cells are recovered after treatment with carbachol, but that, unlike control cells, they do not contain AChR clusters. It also illustrates some of the shape changes (compare cell indicated by the white arrows in $A$ and $B$ ) and occasional vacuolization (e.g., the cell indicated by the black arrowhead in $B$ ) that treatment with carbachol may induce. The clearer view of the nuclei in $C$, compared to $E$, is due to the fact that the cell in $C$ is spread more, and not to any significant change in the appearance of the myoplasm after carbachol treatment. The bar in $F$ represents $20 \mu \mathrm{m}$ for panels $C-F$, and $80 \mu \mathrm{m}$ for panels $A$ and $B$. 
Table 2. Reversibility of carbachol-induced loss of AChR clusters

Myotubes with clusters (\%)

\begin{tabular}{|c|c|c|c|c|c|c|}
\hline \multirow[b]{4}{*}{ Experiment } & \multicolumn{6}{|c|}{ Myotubes with clusters (\%) } \\
\hline & \multicolumn{2}{|c|}{$\begin{array}{l}\text { After initial } \\
\text { incubation }\end{array}$} & \multicolumn{4}{|c|}{ After recovery } \\
\hline & \multirow{2}{*}{$\begin{array}{l}\text { No car- } \\
\text { bachol }^{a}\end{array}$} & \multirow{2}{*}{$\begin{array}{l}\text { Car- } \\
\text { bachol }^{a}\end{array}$} & \multicolumn{2}{|c|}{ No carbachol ${ }^{a}$} & \multicolumn{2}{|c|}{ Carbachol $^{a}$} \\
\hline & & & $\mathrm{A}$ & $\mathbf{B}$ & $\mathrm{A}$ & B \\
\hline 1 & 84 & 14 & 92 & $-b$ & 90 & $--^{b}$ \\
\hline 2 & 87 & 20 & 80 & 80 & 86 & 74 \\
\hline 3 & 64 & 14 & 61 & 64 & 57 & 56 \\
\hline
\end{tabular}

Myotube cultures were incubated with and without carbachol $\left(10^{-4} \mathrm{M}\right)$ for $6 \mathrm{hr}$ at $37^{\circ} \mathrm{C}$. They were then washed extensively. Duplicate samples were withdrawn, stained with R-BT, fixed in cold ethanol, and stored until the termination of the experiment. Data for these samples are given in the columns labeled "After initial incubation." For the samples in column A, remaining cullures were replaced in control medium and incubated at $37^{\circ} \mathrm{C}$ for an additional $16-18 \mathrm{hr}$. Thereafter, they were stained with R-BT and fixed. For the samples in column B, remaining cultures were first stained with R-BT and then replaced in control medium. After the additional incubation, they were fixed without restaining. All samples were mounted in glycerol, and myotubes with clusters were quantitated as described in Methods.

${ }^{a}$ Initial incubation.

${ }^{b}$ Not determined.

control samples) and are harder to visualize. They were, therefore, only examined occasionally.

\section{Pharmacology}

Further experiments, summarized in Table 3, showed that the effects of carbachol are the result of its interaction with AChR. (1) All agonists of the AChR, including neostigmine (Bloch and Stallcup, 1979), cause extensive cluster loss. (2) Partial agonists, such as decamethonium (Adams and Sakmann, 1978), cause less extensive cluster loss. (3) Antagonists, such as $d$-tubocurarine and benzoquinonium, alone have no effect on $\mathrm{AChR}$ clusters, but they reduce or prevent the effect of carbachol. (4) A local anesthetic, QX314, which blocks the AChR ion channel in its open conformation (Neher and Steinbach, 1978), blocks the carbachol-induced loss of AChR clusters. (5) Meproadifen and phenothiazines, which accelerate $\mathrm{AChR}$ desensitization (Carp et al., 1983; Krodel et al., 1979; Maleque et al., 1983), also prevent carbachol-induced cluster loss. Thus, reagents that cause AChR channel opening cause cluster loss, and reagents that block channel opening or reduce the channel open time prevent cluster loss.

The effects of different concentrations of several of these drugs are presented in Figure 3. Carbachol causes half-maximal cluster loss at a concentration of $3 \mu \mathrm{M}$ (Fig. $3 A$ ). Decamethonium shows a biphasic effect on AChR clusters: At $10^{-5} \mathrm{M}$, it causes some cluster loss, but at $10^{-4} \mathrm{M}$ it causes no cluster loss (Fig. $3 B$ ). These dual effects of decamethonium are probably due to the fact (Adams and Sakmann, 1978) that, at lower concentrations, decamethonium interacts with AChR to open some channels, while at higher concentrations it blocks open channels in the manner of a local anesthetic. Over the concentration range $10^{-8}$ $10^{-4} \mathrm{M}, d$-tubocurarine causes no cluster loss and blocks half the effect of $10^{-4} \mathrm{M}$ carbachol at a concentration of $7 \mu \mathrm{M}$ (Fig. $3 C$ ). Fluphenazinc (Fig. $3 D$ ) blocks carbachol-induced cluster loss at the same concentrations at which trifluperazine, a closely related phenothiazine, promotes receptor desensitization (Carp et al., 1983; Maleque et al., 1983). Qualitatively, the results shown in Figure 3 and Table 3 are consistent with the idea that the loss of AChR clusters is a nicotinic cholinergic effect.

\section{Ionic dependence}

Three distinct mechanisms could account for the effect of carbachol on AChR clusters. (1) Carbachol may induce a confor-
Table 3. Effect of cholinergic ligands on $\mathrm{AChR}$ cluster stability

\begin{tabular}{|c|c|c|}
\hline \multirow{2}{*}{$\begin{array}{l}\text { Drug } \\
\text { (concentration) }\end{array}$} & \multicolumn{2}{|c|}{ Myotubes with clusters (\%) } \\
\hline & No carbachol & Carbachol \\
\hline Controls & $81 \pm 6(21)^{a}$ & $23 \pm 10(23)$ \\
\hline \multicolumn{3}{|l|}{ Nicotinic agonists } \\
\hline Nicotine $\left(10^{-4} \mathrm{M}\right)$ & $48 \pm 7$ & $-b$ \\
\hline $\operatorname{DMPP}\left(10^{-4} \mathrm{M}\right)^{r}$ & 10,12 & 20,2 \\
\hline Neostigmine $\left(10^{-4} \mathrm{M}\right)$ & $27 \pm 13(4)$ & $28 \pm 12(3)$ \\
\hline Decamethonium $\left(10^{-5} \mathrm{M}\right)$ & 52,52 & 24,32 \\
\hline \multicolumn{3}{|l|}{ Nicotinic antagonists } \\
\hline $\mathrm{R}-\mathrm{BT}^{d}$ & 87,85 & 80,84 \\
\hline$d$-Tubocurarine $\left(10^{-4} \mathrm{M}\right)$ & $76 \pm 6$ & $74 \pm 10(5)$ \\
\hline Benzoquinonium $\left(10^{-4} \mathrm{M}\right)$ & 78,74 & $82,76^{e}$ \\
\hline \multicolumn{3}{|l|}{ Gallamine } \\
\hline$\left(10^{-4} \mathrm{M}\right)$ & 73,67 & 48,39 \\
\hline$\left(2.5 \times 10^{-4} \mathrm{M}\right)$ & 77 & 67 \\
\hline \multicolumn{3}{|l|}{ Hexamethonium } \\
\hline$\left(5 \times 10^{-4} \mathrm{M}\right)$ & 84,76 & 43,50 \\
\hline \multicolumn{3}{|l|}{ Nicotinic modifiers } \\
\hline \multicolumn{3}{|l|}{ QX314 } \\
\hline$\left(2.5 \times 10^{-4} \mathrm{M}\right)$ & 82 & 75 \\
\hline$\left(5.0 \times 10^{-4} \mathrm{M}\right)$ & 82 & 76,70 \\
\hline Meproadifen $\left(10^{-5} \mathrm{M}\right)$ & 78,79 & 75,70 \\
\hline Fluphenazine $\left(2 \times 10^{-5} \mathrm{M}\right)$ & 80,71 & 82,64 \\
\hline \multicolumn{3}{|l|}{ Related compounds } \\
\hline Muscarine $\left(10^{-4} \mathrm{M}\right)$ & $77 \pm 10(3)$ & 16 \\
\hline \multicolumn{3}{|l|}{ Carbamyl $\beta$-methylcholine } \\
\hline Choline $\left(10^{-4} \mathrm{M}\right)$ & 66,71 & $-b$ \\
\hline Acetylthiocholine $\left(10^{-4} \mathrm{M}\right)$ & $26 \pm 12(3)$ & $21 \pm 17(3)$ \\
\hline
\end{tabular}

Myotube cultures were incubated for $6 \mathrm{hr}$ at $37^{\circ} \mathrm{C}$ with the indicated drug, alone or together with $10^{-4} \mathrm{M}$ carbachol. Cultures were washed extensively to remove the ligands, stained with R-BT, fixed in cold ethanol, and mounted in glycerol. Myotubes with clusters were quantitated as described in Methods.

${ }^{a}$ Mean $\pm \mathrm{SD}$, followed by the number of determinations, in parentheses.

${ }^{b}$ Not determined.

c DMPP, 1,1-dimethyl-4-phenylpiperazinium iodide.

${ }^{t}$ Cultures were preincubated with $5 \mu \mathrm{g} / \mathrm{ml} \mathrm{R}$-BT for $20 \mathrm{~min}$. Cultures were then washed extensively and incubated for $6 \mathrm{hr}$, as for the other samples.

'Value obtained when carbachol alone gave only $49 \%$ myotubes with clusters.

mational change in AChR that is sufficient to induce cluster loss. (2) Ion flux through the receptor ion channel must occur. (3) Depolarization, which is long-lasting in carbachol-treated rat myotubes (Ritchie and Fambrough, 1975a), is sufficient to cause cluster loss.

The results reported in Table 2 make the first possibility unlikely. For example, QX314 does not appear to alter the rates of channel opening and closing or of receptor desensitization (Neher and Steinbach, 1978). As QX314 inhibits the effects of carbachol, the conformational changes associated with these receptor functions are apparently not sufficient to cause cluster loss. I therefore concentrated on the latter two possibilities.

To test the third possibility, I incubated myotubes in medium containing $145 \mathrm{mM} \mathrm{K}^{+}$. When the counterion was chloride, cluster loss was extensive (giving $<10 \%$ myotubes with clusters, in two experiments) and was accompanied by swelling of the myotubes and other morphological changes. (Additional changes in the appearance of myotubes treated with high concentrations of $\mathrm{KCl}$ include the presence of more clearly defined nuclei, with darkened nuclear envelope, lighter nucleoplasm, and condensed 


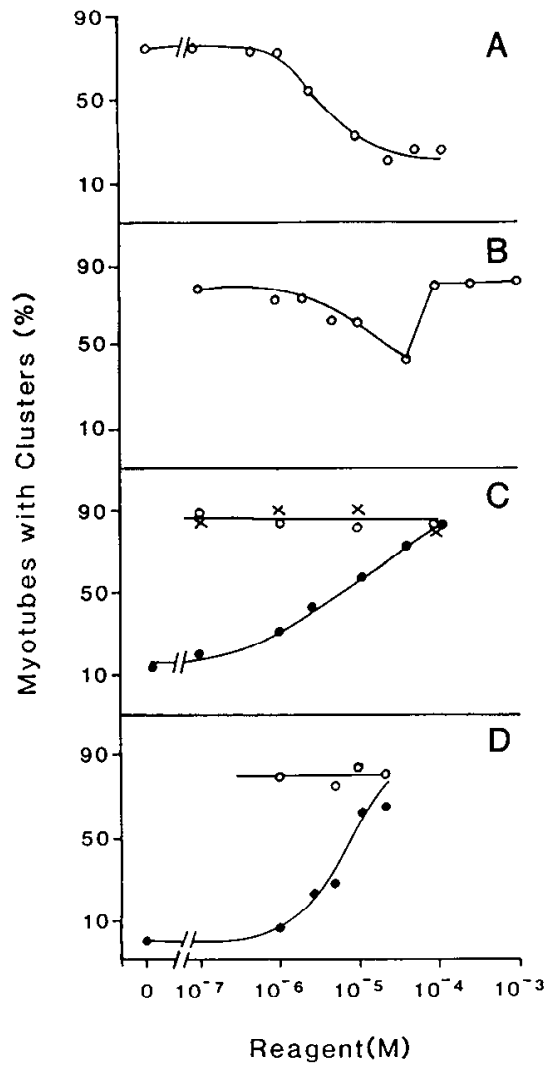

Figure 3. Concentration dependence of the effect of receptor ligands on AChR cluster stability. Myotube cultures were incubated in medium containing the concentration of ligand(s) indicated on the abscissa. After $6 \mathrm{hr}$ at $37^{\circ} \mathrm{C}$, cultures were washed extensively, stained with R-BT, fixed in cold ethanol, and observed under fluorescence optics. Myotubes with clusters were quantitated as described in Methods. $A$, Carbachol shows a half-maximal effect on cluster stability at $2.5 \mu \mathrm{M}$. $B$, Decamethonium shows a biphasic effect. $C$, Benzoquinonium $(\times)$ and $d$-tubocurarine $(O)$ alone have no effect on AChR clusters, but $d$-tubocurarine in the presence of $10^{-4} \mathrm{M}$ carbachol $(\bullet)$ inhibits cluster loss with a half-maximal effect at $7 \mu \mathrm{M} . D$, Trifluperazine alone $(O)$ has no effect on cluster stability, but in the presence of $10^{-4} \mathrm{M}$ carbachol $(\Theta)$, it inhibits cluster loss with a half-maximal effect occurring between 5 and $10 \mu \mathrm{M}$.

nucleoli. These changes are not observed in myotubes treated with carbachol or with K-methane sulfonate.) When the counterions were $4 \mathrm{mM} \mathrm{Cl}^{-}$and $141 \mathrm{~mm}$ methane sulfonate, however, I found no loss of AChR clusters $(78 \pm 5 \%$ myotubes with clusters, $n=3$ ), and no swelling. As myotubes are depolarized to $-1 \pm 0.7 \mathrm{mV}$ (mean $\pm \mathrm{SD}, n=3$ cells in a single culture, measured with an intracellular microelectrode) by high concentrations of $\mathrm{K}^{+}$-methane sulfonate, depolarization is not sufficient to cause cluster loss.

I ruled out the possibility that $\mathrm{Cl}^{-}$was important for cluster loss in two separate experiments. In medium containing 145 $\mathrm{mM} \mathrm{Na}^{+}$, supplemented with $30 \mathrm{mM} \mathrm{KCl}$ (insufficient to cause cluster loss by itself), and containing $\sim 140 \mathrm{~mm} \mathrm{Cl}^{-}$, carbachol treatment was unable to disrupt AChR clusters $(67 \pm 10 \%$ myotubes with clusters, $n=3$ ). Under these conditions, elevated $\mathrm{K}^{+}$ may reduce $\mathrm{Na}^{+}$movement through the AChR ion channel by competing for access to the channel, and also by reducing the driving force for $\mathrm{Na}^{+}$influx. In the second experiment, carbachol treatment in the presence of $4 \mathrm{mM} \mathrm{KCl}$ and $141 \mathrm{~mm} \mathrm{Na}$-methane sulfonate resulted in normal cluster loss $(43 \%$ myotubes with clusters, compared to $40 \%$ in medium containing $145 \mathrm{~m} \mathrm{M} \mathrm{Cl}^{-}$, in a single experiment). Both these experiments suggest that $\mathrm{Cl}^{-}$ is not essential for cluster loss to occur in the presence of carbachol.

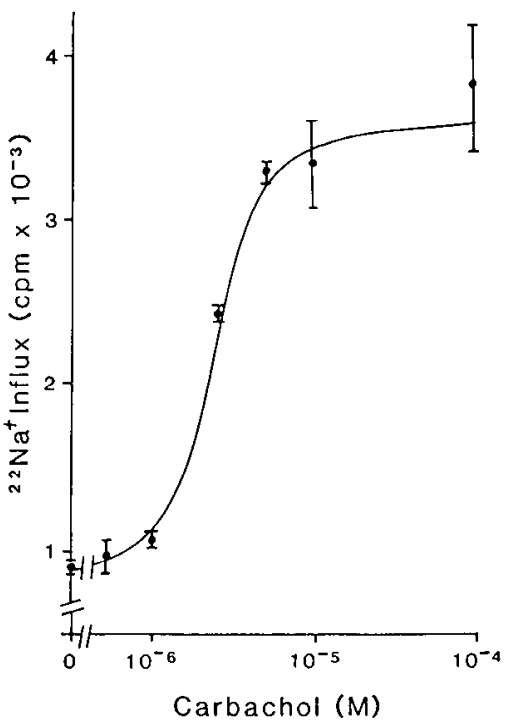

Figure 4. Concentration dependence of carbachol-induced ${ }^{22} \mathrm{Na}^{+}$influx into myotube cultures. Cultures were placed into a balanced salt solution (Bloch, 1983) containing radioactive $\mathrm{Na}^{+}$at $35-37^{\circ} \mathrm{C}$ in the presence of the indicated concentration of carbachol. After $15 \mathrm{~min}$, cultures were rapidly washed free of unbound ${ }^{22} \mathrm{Na}^{+}$, and the radioactivity taken up per culture was determined. More details are given in Stallcup and Cohn (1976). Each point is the mean \pm SD of three samples. The results show that over a 15 min incubation period, carbachol stimulates ${ }^{22} \mathrm{Na}^{+}$uptake by myotube cultures with a half-maximal concentration of approximately $3 \mu \mathrm{M}$.

The most likely explanation of the effects of carbachol on AChR clusters is that carbachol treatment causes an influx of cations into the myotube, altering the intracellular milieu and thereby destabilizing clusters. As $\mathrm{Na}^{+}$is the predominant cation in culture medium that can permeate the AChR channel (Huang et al., 1978; Ritchie and Fambrough, 1975b; Takeuchi and Takeuchi, 1960), I attempted to correlate $\mathrm{Na}^{+}$entry into myotubes with carbachol-induced cluster loss. I first determined the dependence of ${ }^{22} \mathrm{Na}^{+}$influx on carbachol concentration, assaying after $15 \mathrm{~min}$ at $37^{\circ} \mathrm{C}$, as a compromise between conditions used for kinetic measurements $(5-10 \mathrm{sec})$ and those used to observe cluster loss (2-6 hr). As shown in Figure 4, the concentration of carbachol that gave a half-maximal " ${ }^{2} \mathrm{Na}^{+}$influx was $3 \mu \mathrm{M}$ (Fig. 3A). The similar half-maximal concentrations for cluster loss and ${ }^{22} \mathrm{Na}^{+}$influx suggest that the two processes are related. Second, I found that lowering the extracellular $\mathrm{Na}^{+}$concentration reduces the effect of carbachol. The data in Figure $5 B$ show that partial protection against cluster loss was obtained when the extracellular $\mathrm{Na}^{+}$concentration was reduced to $60 \mathrm{mM}$. At $\left[\mathrm{Na}^{+}\right]_{0}$, less than $30 \mathrm{~mm}$, myotubes contracted and were lost from cultures, perhaps because $\mathrm{Ca}^{2+}$ influx through the $\mathrm{AChR}$ ionophore contributed more to net cation influx (e.g., Huang et al., 1978; Stallcup, 1979). These results are consistent with the idea that $\mathrm{Na}^{+}$flux into myotubes is at least in part responsible for AChR cluster loss induced by carbachol.

Two additional observations support this idea. (1) Veratridine, an alkaloid that specifically opens voltage-gated $\mathrm{Na}^{+}$channels in excitable cells (Catterall and Nirenberg, 1973; Stallcup and Cohn, 1976), causes extensive AChR cluster loss. At $2.5 \times$ $10^{-4} \mathrm{M}$, veratridine left only $21 \pm 14 \%(n=3)$ of myotubes with clusters. At the same time, however, it causes severe changes in cell shape. (2) Gramicidin S, an ionophore that forms specific channels for $\mathrm{Na}^{+}$and $\mathrm{K}^{+}$in cell membranes (Jain, 1972), at 10 $\mu \mathrm{g} / \mathrm{ml}$ also causes significant $\mathrm{AChR}$ cluster loss (leaving 35 and $14 \%$ myotubes with clusters in two experiments). At higher concentrations, however, this reagent causes massive contraction and cell loss. Despite the difficulties involved in their use, 


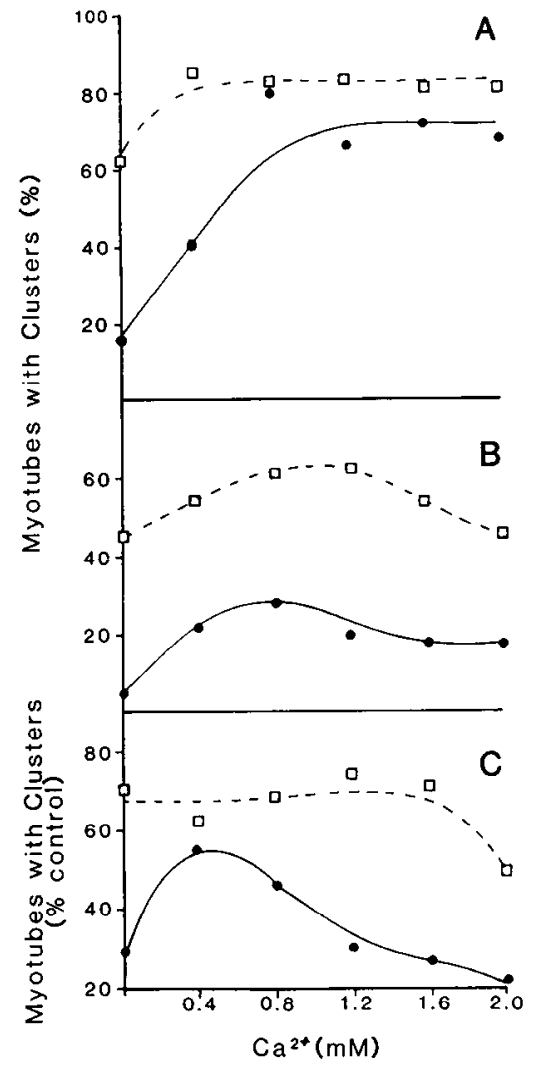

Figure 5. Effect of altering the extracellular salt concentrations on cluster loss induced by carbachol. Myotube cultures were placed into tissue culture medium containing the concentration of $\mathrm{Ca}^{2+}$ indicated on the abscissa, and either $150 \mathrm{~mm} \mathrm{NaCl}$ (closed circles) or $60 \mathrm{~mm} \mathrm{NaCl}$ (open squares). Isotonicity was maintained by the addition of sucrose. Cultures were then incubated either in the absence $(A)$ or presence $(B)$ of $10^{-4} \mathrm{M}$ carbachol for $6 \mathrm{hr}$ at $37^{\circ} \mathrm{C}$. After staining with R-BT and fixation, AChR clusters were quantitated as described in Methods. The raw data are presented in $A$ and $B$. Panel $C$ shows the results cxpressed as the percent control values, which were obtained by dividing the values found in the presence of carbachol $(B)$ by the values found in its absence $(A)$ under otherwise identical conditions. In agreement with other reports (Bloch, 1983; Bursztajn et al., 1984), the results show that lowering extracellular $\mathrm{Ca}^{2+}$ causes $\mathrm{AChR}$ cluster loss $(A$, solid line $)$ and that this requires the presence of high extracellular $\mathrm{Na}^{+}(A$, dotted line $)$. In the presence of carbachol ( $B$ and, after normalization, $C$ ), lowering extracellular $\mathrm{Na}^{+}$protects most of the AChR clusters from disruption (dotted lines). This protection is extended to more myotubes with clusters when extracellular $\mathrm{Ca}^{2+}$ is lowered (solid lines).

both these reagents increase the permeability to $\mathrm{Na}^{+}$, and both cause the loss of AChR clusters. Any means of increasing $\mathrm{Na}^{+}$ influx may therefore disrupt AChR clusters.

As lowering extracellular $\mathrm{Na}^{+}$only partially protects against cluster loss, $\mathrm{Na}^{+}$is probably not the only cation involved, however. As reported elsewhere (Bloch, 1983; Bursztajn et al., 1984) lowering $\left[\mathrm{Ca}^{2+}\right]_{0}$ to concentrations below $0.4 \mathrm{~mm}$ causes cluster loss, and this loss is prevented by simultaneously reducing $\left[\mathrm{Na}^{+}\right]_{0}$ (Fig. $5 A$ ). The effect of very low concentrations of extracellular $\mathrm{Ca}^{2+}$ on carbachol-induced AChR cluster loss could therefore not be determined. At $\left[\mathrm{Ca}^{2+}\right]_{0}$ between 0.4 and $2.0 \mathrm{~mm}$, however, I observed greater protection against the effects of carbachol. In medium containing $60 \mathrm{mM} \mathrm{Na}^{+}$, decreased $\left[\mathrm{Ca}^{2+}\right]_{0}$ prevented an additional $10-20 \%$ of cluster loss (Fig. 5B, dotted line). After normalization for the effects of the changes in salt concentration on controls, however, lower $\left[\mathrm{Ca}^{2+}\right]_{0}$ at $60 \mathrm{~mm} \mathrm{NaCl}$ only gave additional protection against carbachol-induced cluster loss in the upper range of concentrations assayed (Fig. $5 C$, dotted line). With $\left[\mathrm{Na}^{+}\right]_{0}$ constant at $150 \mathrm{~mm}$, reduced $\left[\mathrm{Ca}^{2+}\right]_{0}$ also protected
Table 4. Effect of protease inhibitors on $\mathrm{AChR}$ cluster loss induced by carbachol

\begin{tabular}{|c|c|c|c|c|}
\hline \multirow[b]{2}{*}{ Exp. } & \multirow[b]{2}{*}{$\begin{array}{l}\text { Preincu- } \\
\text { bation } \\
\text { time } \\
\text { (hr) }\end{array}$} & \multirow[b]{2}{*}{ Inhibitor } & \multicolumn{2}{|c|}{$\begin{array}{l}\text { Myotubes with } \\
\text { clusters (\%) }\end{array}$} \\
\hline & & & $\begin{array}{l}\text { No } \\
\text { car- } \\
\text { bachol }\end{array}$ & $\begin{array}{l}\text { Car- } \\
\text { bachol }\end{array}$ \\
\hline \multirow[t]{3}{*}{1} & \multirow[t]{3}{*}{1} & Control & 86 & 6 \\
\hline & & Leupeptin $(25 \mu \mathrm{M})$ & 86 & 26 \\
\hline & & Aprotinin $(0.5 \mathrm{TIU} / \mathrm{ml})^{a}$ & 80 & 20 \\
\hline \multirow[t]{4}{*}{2} & \multirow[t]{4}{*}{1} & Control & 83 & 19 \\
\hline & & Leupeptin $(50 \mu \mathrm{M})$ & 83 & 20 \\
\hline & & Aprotinin $(0.5 \mathrm{TIU} / \mathrm{ml})$ & $-{ }^{b}$ & 12 \\
\hline & & Pepstatin $(50 \mu \mathrm{g} / \mathrm{ml})$ & 72 & 29 \\
\hline \multirow[t]{2}{*}{3} & \multirow[t]{2}{*}{1} & Control & 73 & 14 \\
\hline & & Leupeptin $(250 \mu \mathrm{M})$ & 70 & 24 \\
\hline \multirow[t]{3}{*}{4} & \multirow[t]{3}{*}{16} & Control & 77 & $49^{c}$ \\
\hline & & Leupeptin $(250 \mu \mathrm{M})$ & 66 & 35 \\
\hline & & Ep $475(100 \mu \mathrm{M})$ & 67 & $42^{d}$ \\
\hline \multirow[t]{4}{*}{5} & \multirow[t]{4}{*}{16} & Control & 71 & 23 \\
\hline & & Leupeptin $(50 \mu \mathrm{M})$ & 68 & 18 \\
\hline & & Ep475 $(250 \mu \mathrm{M})$ & 65 & 19 \\
\hline & & $\begin{array}{l}\text { Leupeptin }(50 \mu \mathrm{M}) \text { plus } \\
\text { Ep475 }(250 \mu \mathrm{M})\end{array}$ & 59 & 21 \\
\hline
\end{tabular}

Myotubes were preincubated with protease inhibitor at the desired concentration for the period of time noted. Carbachol was then added to half of the cultures to a final concentration of $10^{-4} \mathrm{M}$. After $6 \mathrm{hr}$ of incubation at $37^{\circ} \mathrm{C}$, cultures were washed, stained with R-BT, fixed, and observed for AChR clusters.

${ }^{a}$ The units are: TIU, trypsin inhibitory units, as defined by the manufacturer (Sigma).

b Not determined.

In experiment 4, carbachol had a less marked effect than in most of the other experiments reported here. Usually when this occurred, inhibitors of cluster loss were more potent. In this case, however, protease inhibitors were unable to protect a significant number of receptor clusters from the disnuptive effects of carbachol, despite the fact that they were used at high concentrations.

${ }^{d}$ This difference is within the standard range of variability for such measurements (see Methods).

clusters from disruption (Fig. $5 B$, solid line). This effect is even more apparent when normalized to account for changes in the control values at the same salt concentrations (Fig. $5 C$, solid line). These experiments suggest that $\left[\mathrm{Ca}^{2+}\right]_{0}$ may also be involved in the loss of AChR clusters caused by carbachol.

\section{Protease inhibitors}

Salpeter and her colleagues (Leonard and Salpeter, 1979; Salpeter et al., 1982b) have reported that alterations in postsynaptic morphology of muscle caused by carbachol may be due to $\mathrm{Ca}^{2+}$ influx into the end-plate region and subsequent activation of $\mathrm{Ca}^{2+}$-dependent neutral proteases. Carbachol-induced damage is reduced in muscles incubated in medium lacking $\mathrm{Ca}^{2+}$ or in medium containing the protease inhibitor, leupeptin (Salpeter et al., 1982b). It seemed reasonable to postulate that AChR clusters in cultured myotubes might be disrupted by a similar mechanism. I therefore treated myotube cultures with leupeptin or with an inhibitor specific for $\mathrm{Ca}^{2+}$-activated thiol proteases, Ep475 (Rodemann et al., 1982), for up to $16 \mathrm{hr}$, to allow the reagents to gain access to the cytoplasmic compartment, then exposed them to carbachol for $6 \mathrm{hr}$ in the continued presence of these reagents. The results of these experiments (Table 4) show that neither leupeptin nor Ep475 protects myotubes from carbachol-induced AChR cluster loss. Aprotinin and pepstatin (Table 4), and L-seryl-L-leucine (not shown), also failed to inhibit 
Table 5. Effects of other drugs and treatments on AChR cluster loss induced by carbachol treatment

\begin{tabular}{|c|c|c|}
\hline \multirow{2}{*}{$\begin{array}{l}\text { Treatment or drug } \\
\text { (concentrations) }\end{array}$} & \multicolumn{2}{|c|}{ Myotubes with clusters (\%) } \\
\hline & No carbachol ${ }^{a}$ & Carbachol \\
\hline None & $81 \pm 6(21)^{b, c}$ & $23 \pm 10(23)^{c}$ \\
\hline $\mathrm{BaCl}_{2}(2 \mathrm{mM})$ & 79,68 & $46 \pm 6$ \\
\hline $\mathrm{MnCl}_{2}(2 \mathrm{~mm})$ & 78,68 & $21 \pm 14(3)$ \\
\hline $\mathrm{SrCl}_{2}(2 \mathrm{~mm})$ & $77,90^{d}$ & 25,10 \\
\hline $\mathrm{CoCl}_{2}(2 \mathrm{~mm})$ & 73,62 & $7 \pm 5$ (4) \\
\hline $\mathrm{MgCl}_{2}(4 \mathrm{mM})^{e}$ & $64,86^{d}$ & 6,25 \\
\hline Ouabain ( $5 \mathrm{~mm}$ ) & 69,62 & 20,4 \\
\hline Colchicine $\left(10^{-5} \mathrm{M}\right)$ & $69 \pm 6$ & 22,22 \\
\hline Cytochalasin B $(2 \mu \mathrm{g} / \mathrm{ml})$ & $84 \pm 5$ & 31,15 \\
\hline Cycloheximide $(50 \mu \mathrm{g} / \mathrm{ml})$ & $66 \pm 11(3)$ & 10,12 \\
\hline Concanavalin A $(10 \mu \mathrm{g} / \mathrm{ml})$ & 91,83 & $62 \pm 6$ \\
\hline Prefixation' & 70,73 & 84,82 \\
\hline Room temperature ${ }^{g}$ & 76,76 & 84,62 \\
\hline
\end{tabular}

Myotube cultures were incubated in the presence of the drugs listed, with or without carbachol $\left(10^{-4} \mathrm{M}\right)$, for $6 \mathrm{hr}$ at $37^{\circ} \mathrm{C}$. Cultures were then washed, stained with R-BT, fixed, and analyzed for myotubes with AChR clusters.

${ }^{a}$ Unless otherwise indicated, the values in this column are from Bloch (1979, 1983).

"When appropriate, results are expressed as means \pm SD, followed by the number of determinations (in parentheses).

Values from Table 2.

${ }^{d}$ Values not previously reported.

" The medium already contained $2 \mathrm{mM} \mathrm{MgCl}_{2}$, so the final concentration was 6 $\mathrm{mm}$.

${ }^{f}$ Samples were fixed for $5 \mathrm{~min}$ at $22^{\circ} \mathrm{C}$ in $2 \%$ (wt/vol) paraformaldehyde in buffered saline before being placed into incubation with or without carbachol.

${ }^{8}$ Incubations were conducted as for the other samples described, but the temperature was kept at $22^{\circ} \mathrm{C}$.

cluster loss in the presence of carbachol. These results suggest that carbachol does not cause cluster loss in cultured myotubes solely by activating $\mathrm{Ca}^{2+}$-dependent neutral proteases.

\section{Other drugs}

To define further the possible changes in myotubes caused by carbachol, I examined the effects of several other treatments and drugs (Table 5). Only prefixation with paraformaldehyde, incubation at room temperature, or incubation in the presence of concanavalin A protected against cluster loss, perhaps by reducing the mobility of $\mathrm{AChR}$ in the myotube membrane. $\mathrm{Ba}^{2+}$, but no other divalent cation, gave partial protection. Colchicine, which partially protects against AChR cluster loss in $\mathrm{Ca}^{2+}$-free medium (Bloch, 1983), had no effect. Ouabain, which should potentiate the increase in intracellular $\mathrm{Na}^{+}$initiated by carbachol, increased both cluster loss and loss of myotubes due to contraction. Other drugs that had no effect on the loss of clusters induced by carbachol include $3^{\prime}, 5^{\prime}$-cAMP, 3', $5^{\prime}$-cGMP, and their dibutyryl derivatives, all assayed at $1 \mathrm{~mm}$ in the presence or absence of theophylline ( $1 \mathrm{mM})$, theophylline alone (1 $\mathrm{mM})$, caffeine ( $2 \mathrm{mM})$, dimethylsulfoxide $(1 \%)$, and ethanol ( $1 \%)$. Other neurotransmitter agonists and antagonists also failed to alter AChR cluster stability. Reagents tested include histamine, glycine, glutamate, $\gamma$-aminobutyric acid, epinephrine, norepinephrine, and serotonin, all at $10^{-4} \mathrm{M}$.

\section{Discussion}

\section{Nicotinic cholinergic effect}

Exposure of cultured rat myotubes to carbachol causes the disappearance of $\mathrm{AChR}$ clusters from the myotube membrane. The mechanism of this disappearance, or loss, is still not known.
Several possibilities are highly unlikely, however. (1) Cluster loss is not the result of massive loss of myotubes or of irreversible damage to the myotubes. (2) It is probably not the result of the changes in cell shape accompanying exposure to carbachol. More extensive changes in shape are induced by exposure to colchicine, for example, without significant cluster loss. Furthermore, myotube-substrate contacts, at which clusters are often found (e.g., Bloch and Geiger, 1980; Land et al., 1977), are not significantly altered during carbachol treatment (R. J. Bloch, unpublished observations), and the organization of membrane domains in this region of the cell is not lost as clusters are disrupted during exposure to carbachol (D. W. Pumplin and R. J. Bloch, unpublished observations). These observations suggest that carbachol does not grossly deform the regions of the myotubes at which clusters are normally found. (3) Cluster loss is probably not the result of the shedding of clusters from the cell. In cases where this has been observed (e.g., Bloch, 1984, and unpublished observations), clusters are shed onto the adjacent tissue culture substrate. No such shedding was observed in these experiments. (4) Disappearance is probably not the result of carbachol remaining bound or trapped by clustered receptors. Instead, the results presented here show that the loss of AChR clusters seen in rat myotube cultures treated with carbachol is a pharmacological effect mediated by ion flux through the AChR channels.

The pharmacology of cluster loss is nicotinic cholinergic. Cluster loss is caused by a variety of nicotinic agonists and blocked by classical nicotinic antagonists, including BT. It is also inhibited by the local anesthetic, QX314, and by meproadifen. As argued in Results, the effects of these drugs are not consistent with the idea that carbachol causes the loss of AChR clusters simply because it induces a conformational change in the receptors that renders them less able to cluster. Instead, some effect that follows agonist-induced conformational changes must be responsible for cluster loss in the presence of carbachol. This effect is not simply membrane depolarization, however, as $\mathrm{K}^{+}$ at high concentrations (with methane sulfonate as the counterion) does not cause the loss of AChR clusters. Thus, cluster loss probably results from the flux of particular ions through the AChR channels opened by carbachol.

Several results suggest that, of the cations that permeate the AChR channel, $\mathrm{Na}^{+}$is the most important. (1) Carbachol stimulates ${ }^{22} \mathrm{Na}^{+}$flux and cluster loss with the same half-maximal concentration. (2) Two other reagents that stimulate $\mathrm{Na}^{+}$influx, veratridine and gramicidin, also cause AChR cluster loss. (3) Reducing extracellular $\mathrm{Na}^{+}$concentrations prevents much cluster loss. This interpretation is also consistent with the observed effect of electrical activity on AChR clusters. For example, Axelrod et al. (1978) showed that repeated electrical stimulation of myotube cultures caused the AChR clusters to be lost. Such stimulation would tend to increase intracellular $\mathrm{Na}^{+}$. Several investigators have further reported that TTX, which should block spontaneous opening of the voltage-activated $\mathrm{Na}^{+}$channel and thereby prevent an increase in intracellular $\mathrm{Na}^{+}$levels due to such openings, promotes the formation of AChR clusters (e.g. Harris, 1981; Prives et al., 1976; Ziskind-Conhaim and Bennett, 1982). Treatments that increase $\left[\mathrm{Na}^{+}\right]_{i}$ are therefore likely to disrupt AChR clusters, and treatments that block such increases are likely to promote cluster formation.

One difficulty with this interpretation is that the concentrations of nicotinic drugs needed to affect AChR clusters do not consistently agree with published values of their affinities for AChR on the surface of mammalian cells (e.g., Patrick et al., 1977; Sine and Taylor, 1979, 1981). These differences are probably the consequence of studying long-term effects, involving processes other than AChR channel opening (e.g., a gradual reduction in the driving force for $\mathrm{Na}^{+}$influx or a change in the activity of the $\mathrm{Na}^{+}-\mathrm{K}^{+}$pump). A similar half-maximal concen- 
tration for carbachol has been reported by Lindstrom et al. (1980), who studied ${ }^{22} \mathrm{Na}^{+}$flux into small vesicles, stimulated by carbachol interacting with $\mathrm{AChR}$, at times much later than those required to observe true initial velocities.

A second possible difficulty with this interpretation is the observation by Ziskind and Dennis (1978) and others (Morris et al., 1983; Trautmann, 1982) that $d$-tubocurarine can act as a nicotinic agonist in embryonic rat muscle. Ziskind and Dennis (1978) report, however, that bath application of $d$-tubocurarine to embryonic muscle depolarizes embryonic muscle fibers to $-50 \mathrm{mV}$. In contrast, carbachol causes long-lasting depolarization of cultured rat myotubes to 0 to $-10 \mathrm{mV}$ (Ritchie and Fambrough, 1975a). Thus, $d$-tubocurarine probably fails to disrupt clusters because it is not a sufficiently potent receptor agonist.

\section{Role of $\mathrm{Ca}^{7+}$}

Although $\mathrm{Na}^{+}$flux through the AChR channel appears to be important for cluster loss to occur in the presence of carbachol, it may not be sufficient. Some protection against cluster loss is afforded by reducing extracellular $\mathrm{Ca}^{2+}$ concentrations two- to fourfold, and nearly complete protection is afforded by reducing both $\mathrm{Na}^{+}$and $\mathrm{Ca}^{2+}$. In addition, $\mathrm{Ba}^{2+}$ partially blocks cluster loss (Table 5) without interfering with carbachol-stimulated ${ }^{22} \mathrm{Na}^{+}$ influx (Bloch, unpublished observations). $\mathrm{Ba}^{2+}$ is more likely to act at divalent than at monovalent cation binding sites. I tentatively conclude, therefore, that both $\mathrm{Na}^{+}$and $\mathrm{Ca}^{2+}$ promote AChR cluster loss in the presence of carbachol.

How does the movement of $\mathrm{Na}^{+}$through the AChR ion channel, in the presence of extracellular $\mathrm{Ca}^{2+}$, destabilize AChR clusters? Answering this question requires that we know where $\mathrm{Ca}^{2+}$ acts. In principle, its site of action could be intracellular, extracellular, or within the plasma membrane. If $\mathrm{Ca}^{2+}$ acts intracellularly, its intracellular concentrations may be elevated via a $\mathrm{Na}^{+}$-for-Ca ${ }^{2+}$ exchange mechanism (e.g., Blaustein and Nelson, 1981) driven by high $\left[\mathrm{Na}^{+}\right]_{1}$. Other investigators and I have argued that depletion of intraccllular $\mathrm{Ca}^{2+}$ causes disruption of the AChR clusters of cultured rat myotubes (Bloch, 1983; Bursztajn et al., 1984). If a rise in intracellular $\mathrm{Ca}^{2+}$ is an important factor in carbachol-induced cluster loss, then, to account for all my results, receptor clustering would have to show a "bellshaped" or biphasic dependence on intracellular $\mathrm{Ca}^{2+}$. This would be consistent with the data in Figure $5 C$ (solid line). A disruptive effect on clusters of increased intracellular $\mathrm{Ca}^{2+}$ would also be consistent with observations (Bloch, unpublished observations) that the ionophore, A23187 at concentrations that cause contraction and loss of some myotubes, causes cluster loss in most remaining cells. However, in two experiments using carbachol, I have failed to observe increased ${ }^{45} \mathrm{Ca}^{2+}$ influx into myotubes (unpublished observations). It is therefore possible that $\mathrm{Ca}^{2+}$ influx does not increase during carbachol treatment.

It is difficult, nevertheless, to account for the effect of $\mathrm{Ca}^{2+}$ by postulating that it acts either extracellularly or at the level of the plasma membrane. Based on their observation that high extracellular $\mathrm{Ca}^{2+}$ induces cluster growth, Bursztajn et al. (1984) suggested that $\mathrm{Ca}^{2+}$ might promote interaction of the muscle membrane with "extracellular elements," thereby stabilizing AChR clusters. Several authors have also suggested that increased local concentrations of $\mathrm{Ca}^{2+}$ might promote AChR desensitization (Magazanik and Vyskocil, 1970; Manthey, 1966; Nastuk and Parsons, 1970). The observation that lowering, rather than raising, extracellular $\mathrm{Ca}^{2+}$ protects against cluster loss is inconsistent with the possibility that changes in these interactions account for the loss of AChR clusters induced by carbachol.

Other investigators have suggested specific molecules that might mediate the affect of $\mathrm{Ca}^{2+}$ on the stability of AChR-rich membrane. Salpeter and her colleagues (Leonard and Salpeter, 1979; Salpeter et al., 1982b) have shown that increased post- synaptic $\mathrm{Ca}^{2+}$ concentrations can activate neutral proteases, and that this causes disruption of postsynaptic morphology. To learn if similar enzymes participate in cluster loss in rat myotubes treated with carbachol, I treated myotube cultures with specific protease inhibitors. Such treatments gave little protection of clusters (Table 4). $\mathrm{Ca}^{2+}$-activated neutral proteases are therefore probably not involved.

Peng (1984) has suggested that calmodulin might be involved in regulation of $\mathrm{AChR}$ clustering. This possibility is difficult to assess. All organic inhibitors of calmodulin, including fluphenazine (Landry et al., 1981; Weiss et al., 1980), exert their effects on calmodulin at micromolar concentrations. At these same concentrations, the phenothiazines promote AChR desensitization (Carp et al., 1983; Maleque et al., 1983), a process that alone should protect against cluster loss caused by carbachol. In the same concentration range, these and other calmodulin inhibitors can also act as local anesthetics (e.g., Creese et al., 1978; Seeman, 1972). It is therefore difficult to distinguish the effects of these drugs on calmodulin from their effects on AChR and on general membrane structure.

In summary, it is not yet clear how or where $\mathrm{Ca}^{2+}$ participates in the disruption of AChR clusters induced by carbachol, nor is the identity of the macromolecules that mediate the action of $\mathrm{Ca}^{2+}$ apparent.

\section{Local effects of carbachol}

Although carbachol may interact equally well with AChR anywhere in the muscle membrane, it may promote cluster loss by interacting with the receptors within clusters. About $10 \%$ of the total number of $\mathrm{AChR}$ in cultures of rat myotubes are in clusters, where they are present at densities 10 -fold higher than receptors elsewhere on the cell surface (Axelrod et al., 1976; Land et al., 1977; Salpeter et al., 1982a). When these clustered AChR bind carbachol, the local ionic changes that result may be greater than those occurring away from clusters. This may help to explain somc of the differences betwcen myotubes treated with carbachol and those treated with veratridine or gramicidin. The former change shape slightly (e.g., Fig. 1), but the latter tend to swell and contract. Both veratridine and gramicidin would probably promote $\mathrm{Na}^{+}$flux more or less uniformly around the muscle membrane. They may cause relatively uniform increases in ionic concentration throughout the myoplasm and induce shape changes or contraction at the same drug concentrations that cause cluster loss. Because its effects would be enhanced in areas of high AChR density, carbachol might alter cluster stability before it grossly affected cell shape.

The potentially disruptive effect of carbachol on AChR clusters suggests that only low levels of neurotransmission may be tolerated at early stages of development of the neuromuscular junction. This is consistent with several observations. The initial formation of $\mathrm{AChR}$ aggregates at the developing postsynaptic membrane does not require functional neurotransmission (Anderson and Cohen, 1977; Anderson et al., 1977; Dennis et al., 1981). Electrical or synaptic activity more intense than that seen at developing synapses (Dennis et al., 1981) seems to prevent or reverse the formation of postsynaptic receptor aggregates. For example, electrical stimulation suppresses receptor accumulation at newly forming ectopic synapses in denervated adult muscle (Lomo and Slater, 1978). Also, as with cultured myotubes, exposure of the intact, embryonic rat muscle to carbachol causes the disappearance of postsynaptic AChR aggregates (Bloch and Steinbach, 1981). During development, as the frequency and intensity of transmission at the neuromuscular junction increase (see Diamond and Miledi, 1962; Kidokoro et al., 1980; Kullberg et al., 1977), the postsynaptic receptor aggregates become more resistant to disruption by electrical stimulation or cholinergic agonists (Bloch and Steinbach, 1981; Lomo and Slater, 1978). 


\section{Conclusion}

Increased influx of $\mathrm{Na}^{+}$, induced by carbachol or by other treatments, probably destabilizes AChR clusters. The mechanism of destabilization is not yet understood, but two possibilities are worth investigating further. (1) Carbachol could induce the internalization and degradation (down-regulation) of $\mathrm{AChR}$ in primary rat myotubes, as has been reported for chick myotubes and a mouse muscle cell line by others (Gardner and Fambrough, 1979; Noble et al., 1978). Work now in progress has shown that exposure of rat myotube cultures to carbachol reduces the overall number of ${ }^{125}$ I-BT binding sites by about $30 \%$, but neither the time course nor the pharmacology of this decrease correlates with that observed for the loss of AChR clusters (Bloch, unpublished observations). The possibility remains that carbachol causes cluster loss by "down-regulating" the clustered AChRs, which represent only about $10 \%$ of the total ${ }^{125}$ I-BT binding sites on the cell surface. (2) AChR may be stabilized in clusters by binding to intracellular cytoskeletal structures (see Steinbach and Bloch, in press, for a review). Increased $\mathrm{Na}^{+}$influx could reduce this binding or alter the cytoskeletal organization in the vicinity of clusters. Recent progress in isolating AChR clusters from rat myotube cultures by mild detergent extraction (Bloch, 1984) should permit these and other possibilities to be investigated in the near future.

\section{References}

Adams, P. R., and B. Sakmann (1978) Decamethonium both opens and blocks endplate channels. Proc. Natl. Acad. Sci. USA 75: 29942998.

Anderson, M. J., and M. W. Cohen (1977) Nerve-induced and spontaneous redistribution of acetylcholinc reccptors on culturcd muscle cells. J. Physiol. (Lond.) 268: 757-773.

Anderson, M. J., M. W. Cohen, and E. Zorychta (1977) Effects of innervation on the distribution of acetylcholine receptors on cultured muscle cells. J. Physiol. (Lond.) 268: 731-756.

Axelrod, D., P. Ravdin, D. E. Koppel, J. Schlessinger, W. W. Webb, E. L. Elson, and T. R. Podleski (1976) Lateral motion of fluorescently labeled acetylcholine receptors in membranes of developing muscle fibres. Proc. Natl. Acad. Sci. USA 73: 4594-4598.

Axelrod, D., P. M. Ravdin, and T. R. Podleski (1978) Control of acetylcholine receptor mobility and distribution in cultured muscle membranes. A fluorescence study. Biochim. Biophys. Acta 511:2338.

Blaustein, M. P., and M. T. Nelson (1981) Sodium-calcium exchange: Its rolc in the regulation of cell calcium. In Calcium Transport Across Biological Membranes, E. Carafoli, ed., pp. 217-236, Academic, New York.

Bloch, R. J. (1979) Dispersal and reformation of acetylcholine receptor clusters of cultured rat myotubes treated with inhibitors of energy metabolism. J. Cell Biol. 82: 626-643.

Bloch, R. J. (1983) Acetylcholine receptor clustering in rat myotubes: Requirement for $\mathrm{Ca}^{2+}$ and effects of drugs which depolymerize microtubules. J. Neurosci. 3: 2670-2680.

Bloch, R. J. (1984) Isolation of acetylcholine receptor clusters from cultured rat myotubes using saponin. J. Cell Biol. 99: 1084-1093.

Bloch, R. J., and B. Geiger (1980) The localization of acetylcholine receptor clusters in areas of cell-substrate contact in cultures of rat myotubes. Cell 21: 25-35.

Bloch, R. J., and W. B. Stallcup (1979) Agonist action of neostigmine on acetylcholine receptors of cultured mammalian muscle. Brain Res. I72: 378-381.

Bloch, R. J., and J. H. Steinbach (1981) Reversible loss of acetylcholine receptor clusters at the developing rat neuromuscular junction. Dev. Biol. 81: 386-391.

Bursztajn, S., J. L. McManaman, and S. H. Appel (1984) Organization of acetylcholine receptor clusters in cultured rat myotubes is calcium dependent. J. Cell Biol. 98: 507-517.

Carp, J. S., R. S. Aronstam, B. Witkop, and E. X. Albuquerque (1983) Electrophysiological and biochemical studies on enhancement of desensitization by phenothiazine neuroleptics. Proc. Natl. Acad. Sci. USA 80: 310-314.

Catterall, W. A., and M. W. Nirenberg (1973) Sodium uptake asso- ciated with activation of action potential ionophores of cultured neuroblastoma and muscle cells. Proc. Natl. Acad. Sci. USA 70: 37593763.

Creese, I., D. R. Burt, and S. H. Snyder (1978) Biochemical actions of neuroleptic drugs: Focus on the dopamine receptor. In Handbook of Psychopharmacology, Vol. 10, L. L. Iversen, S. D. Iversen, and S. H. Snyder, eds., pp. 39-42, Plenum, New York.

Dennis, M. J., L. Ziskind-Conhaim, and A. J. Harris (1981) Development of neuromuscular junctions in rat embryos. Dev. Biol. 81: 266-279.

Diamond, J., and R. Miledi (1962) A study of foetal and new-born rat muscle fibers. J. Physiol. (Lond.) 162: 393-408.

Fambrough, D. M. (1979) Control of acetylcholine receptors in skeletal muscle. Physiol. Rev. 59: 165-227.

Gardner, J. M., and D. M. Fambrough (1979) Acetylcholine receptor degradation measured by density labeling: Effects of cholinergic ligands and evidence against recycling. Cell 16: 661-674.

Harris, A. J. (1981) Embryonic growth and innervation of rat skeletal muscles. III. Neural regulation of junctional and extrajunctional acetylcholine receptor clusters. Phil. Trans. R. Soc. London [Biol.] 293: 287-314.

Huang, L.-Y. M., W. A. Catterall, and G. Ehrenstein (1978) Selectivity of cations and nonelectrolytes for acetylcholine-activated channels in cultured muscle cells. J. Gen. Physiol. 71: 397-410.

Jain, M. K. (1972) The Bimolecular Lipid Membrane, p. 180, Van Nostrand Reinhold, New York.

Kidokoro, Y., M. J. Anderson, and R. Gruener (1980) Changes in synaptic potential properties during acetylcholine receptor accumulation and neurospecific interactions in Xenopus nerve-muscle cell culture. Dev. Biol. 78: 464-483.

Krodel, E. K., R. A. Beckman, and J. B. Cohen (1979) Identification of local anesthetic binding site in nicotinic postsynaptic membranes isolated from Torpedo marmorata electric tissue. Mol. Pharmacol. 15: 294-312.

Kullberg, R. W., T. L. Lentz, and M. W. Cohen (1977) Development of the myotomal neuromuscular junction in Xenopus laevis: An electrophysiological and fine-structural study. Dev. Biol. 60: 101-129.

Land, B. R., T. R. Podleski, E. E. Salpeter, and M. M. Salpeter (1977) Acetylcholine receptor distribution on myotubes in culture correlated to acetylcholine sensitivity. J. Physiol. (Lond.) 269: 155-176.

Landry, Y., M. Amellal, and M. Ruckstuhl (1981) Can calmodulin inhibitors be used to probe calmodulin effects? Biochem. Pharmacol. 30: 2031-2032.

Leonard, J. P, and M. M. Salpeter (1979) Agonist-induced myopathy at the neuromuscular junction is mediated by calcium. J. Cell Biol. 82: 811-819.

Lindstrom, J., R. Anholt, B. Einarson, A. Engle, M. Osame, and M. Montal (1980) Purification of acetylcholine receptors, reconstitution into lipid vesicles, and study of agonist-induced cation channel regulation. J. Biol. Chem. 255: 8340-8350.

Lomo, T., and C. R. Slater (1978) Control of acetylcholine sensitivity and synapse formation by muscle activity. J. Physiol. (Lond.) 275 : $391-402$.

Magazanik, L. G., and F. Vyskocil (1970) Dependence of acetylcholine desensitization on the membrane potential of frog muscle fibre and on the ionic changes in the medium. J. Physiol. (Lond.) 210: 507518.

Maleque, M. A., C. Souccar, J. B. Cohen, and E. X. Albuquerque (1983) Meproadifen reaction with the ionic channel of the acetylcholine receptor: Potentiation of agonist-induced desensitization at the frog neuromuscular junction. Mol. Pharmacol. 22: 636-647.

Manthey, A. A. (1966) The effect of calcium on the desensitization of membrane receptors at the neuromuscular junction. J. Gen. Physiol. 49: 963-976.

Morris, C. E., B. S. Wong, M. B. Jackson, and H. Lecar (1983) Singlechannel currents activated by curare in cultured embryonic rat muscle. J. Neurosci. 3: 2525-2531.

Nastuk, W. L., and R. L. Parsons (1970) Factors in the inactivation of postjunctional membrane receptors of frog skeletal muscle. J. Gen. Physiol. 56: 218-249.

Neher, E., and J. H. Steinbach (1978) Local anesthetics transiently block currents through single acetylcholine receptor channels. J. Physiol. (Lond.) 277: 153-176.

Noble, M. D., T. H. Brown, and J. H. Peacock (1978) Regulation of acetylcholine receptor levels by a cholinergic agonist in mouse muscle cell cultures. Proc. Natl. Acad. Sci. USA 75: 3488-3492. 
Patrick, J., J. McMillan, H. Wolfson, and J. C. O'Brien (1977) Acetylcholine receptor metabolism in a nonfusing muscle cell line. J. Biol. Chem. 252: 2143-2153.

Peng, H. B. (1984) Participation of calcium and calmodulin in the formation of acetylcholine receptor clusters. J. Cell Biol. 98: 550557.

Prives, J., I. Silman, and A. Amsterdam (1976) Appearance and disappearance of acetylcholine receptor during differentiation of chick skeletal muscle in vitro. Cell 7: 543-550.

Ravdin, P., and D. Axelrod (1977) Fluorescent tetramethylrhodamine derivatives of $\alpha$-bungarotoxin: Preparation, separation and characterization. Anal. Biochem. 80: 585-592; 83: 336 (Erratum).

Ritchie, A. K., and D. M. Fambrough (1975a) Ionic properties of the acetylcholine receptor in clutured rat myotubes. J. Gen. Physiol. 65: $751-767$.

Ritchie, A. K., and D. M. Fambrough (1975b) Electrophysiological properties of the membrane and acetylcholine receptor in developing rat and chick myotubes. J. Gen. Physiol. 66: 327-355.

Rodemann, H. P., L. Waxman, and A. L. Goldberg (1982) The stimulation of protein degradation in muscle by $\mathrm{Ca}^{2+}$ is mediated by prostaglandin $E_{2}$ and does not require the calcium-activated protease. J. Biol. Chem. 257: 8716-8723.

Salpeter, M. M., J. P. Leonard, and H. Kasprzak (1982a) Agonistinduced postsynaptic myopathy. Neurosci. Comment. 1: 73-83.

Salpeter, M. M., S. Spanton, K. Holley, and T. R. Podleski (1982b) Brain extract causes acetylcholinc receptor redistribution which mimics some early events at developing neuromuscular junctions. J. Cell Biol. 93: 417-425.

Seeman, P. (1972) The membrane actions of anesthetics and tranquilizers. Pharmacol. Rev. 24: 583-655.
Sine, S., and P. Taylor (1979) Functional consequences of agonistmediated state transitions in the cholinergic receptor. Studies in cultured muscle cells. J. Biol. Chem. 254: 3315-3325.

Sine, S. M., and P. Taylor (1981) Kelationship between reversible antagonist occupancy and the functional capacity of the acetylcholine receptor. J. Biol. Chem. 256: 6692-6699.

Stallcup, W. B. (1979) Sodium and calcium fluxes in a clonal nerve cell line. J. Physiol. (Lond.) 286: 525-540.

Stallcup, W. B., and M. Cohn (1976) Electrical properties of a clonal cell line as determined by measurement of ion fluxes. Exp. Cell Res. 98: 277-284.

Steinbach, J. H., and R. J. Bloch (in press) Control of acetylcholine receptor distribution in vertebrate skeletal muscle. In Receptors in Cell Recognition and Differentiation, G. B. Price and R. Gorczynski, eds., Academic, New York.

Takeuchi, A., and N. Takeuchi (1960) On the permeability of endplate membrane during the action of transmitter. J. Physiol. (Lond.) 154: 52-67.

Trautmann, A. (1982) Curare can open and block ionic channels associated with cholinergic receptors. Nature 298: 272-275.

Weiss, B., W. Prozialeck, M. Cimino, M. S. Barnette, and T. L. Wallace (1980) Pharmacological regulation of calmodulin. Ann. NY Acad. Sci. 356: 319-345.

Ziskind, L., and M. J. Dennis (1978) Depolarizing effect of curare on embryonic rat muscles. Nature 276: 622-623.

Ziskind-Conhaim, L., and J. I. Bennett (1982) The effects of electrical inactivity and denervation on the distribution of acetylcholine receptors in developing rat muscle. Dev. Biol. 90: 185-197. 